\title{
THREE NEW SHOWY BUT ENDANGERED CYRTOCHILUM SPECIES (ONCIDIINAE: ORCHIDACEAE) FROM PERU
}

\author{
Stig Dalström ${ }^{1,4}$, Guido Deburghgraeve ${ }^{2} \&$ Saul Ruíz Perez ${ }^{3}$ \\ ${ }^{1} 2304$ Ringling Boulevard, unit 119, Sarasota FL 34237, USA \\ Research Associate, Lankester Botanical Garden, University of Costa Rica, Cartago, Costa Rica \\ and National Biodiversity Centre, Serbithang, Bhutan \\ ${ }^{2}$ Meersstraat 147, 1770 Liedekerke, Belgium \\ ${ }^{3}$ Allamanda 142, Surco, Lima 33, Peru \\ ${ }^{4}$ Corresponding author: stigdalstrom@juno.com
}

Aвstract. Three new Cyrtochilum species from Peru that are endangered by habitat destruction, are here described, illustrated and compared with similar species.

KeY words: Cyrtochilum, endangered species, Orchidaceae, Oncidiinae, new species, Peru, taxonomy

The genus Cyrtochilum Kunth has gone through quite a taxonomic turmoil during its two centuries long history. The trouble has mainly been caused by difficulties in defining the genus based on floral morphology alone, and to separate it from genera Odontoglossum Kunth (considered as Oncidium by some) and Oncidium Sw. Other species have been placed in various smaller genera, such as Buesiella C.Schweinf., Neodryas Rchb.f., and Rusbyella Rolfe. Thanks to molecular work with DNA sequencing (Williams et al. 2001a, 2001b) we now know a lot more about how these plants are related to each other, although the controversy of how to treat them taxonomically probably will remain for some time yet. The three large flowered species described in this paper, however, are most certainly considered as "typical" cyrtochilums by most people, so little controversy should arise from their descriptions.

\section{TAXONOMIC TREATMENT}

\section{Cyrtochilum deburghgraeveanum Dalström \&} S.Ruíz, sp. nov.

TYPE: Peru, Amazonas, Jumbilla, Florida, Gualulo, alt. ca $2200 \mathrm{~m}$, collected by S. Ruíz and G. Deburghgraeve, Nov. 2010; S. Dalström 3498 (holotype, USM). FIg. 1.

Cyrtochilo cordato (Lindl.) Kraenzl. similis, sed lobulis lateralibus et callo labelli recedit.

Epiphytic herb. Pseudobulbs caespitose or slightly creeping on a bracteate rhizome, oblong ovoid, $c a$. $10 \times 5 \mathrm{~cm}$, distantly bifoliate (terminal leaf $c a .2$ $\mathrm{cm}$ above lower leaf), surrounded basally by 7-8 distichous sheaths, the uppermost foliaceous. Leaves subpetiolate, conduplicate, narrowly elliptic to slightly obovate, narrowly acute to broadly acuminate, 30$45 \times 1.5-2.5 \mathrm{~cm}$. Inflorescence axillary from the uppermost sheaths, erect, then wiry and flexuous, to $c a .160 \mathrm{~cm}$ long panicle, with widely spaced $3-5$ flowered side branches. Bracts appressed, involute and cucullate, 10-15 mm long. Pedicel with ovary, 20$35 \mathrm{~mm}$ long. Flower stellate to slightly campanulate, showy; dorsal sepal brown with white to yellow edges and apex, spathulate with basal auricles, then laminate, ovate, obtuse to acute, undulate, 13-24 $\times$ 11-12 mm; lateral sepals similar in color, spathulate with basal auricles, laminate, elongate ovate, obtuse to obliquely acute, $25-30 \times 9-10 \mathrm{~mm}$; petals similar in color, broadly spathulate, ovate, obtuse to acute, oblique, undulate, $23-24 \times 10-13 \mathrm{~mm}$; lip white with pale brown front-lobe, rigidly attached to the base of the column, cuneate, trilobate with erect, broadly linear and elongate, obliquely rounded side-lobes, and a narrowly triangular, ligulate, apically slightly convolute, obtuse to acute, recurved front-lobe, 22 $\times 22 \mathrm{~mm}$; callus white, with three low and flattened, fleshy, longitudinal keels emerging from the base and extending to the front-lobe, then spreading, with the lateral pair ending in erect, laterally flattened angulate keels, and with an additional emerging pair of erect, 

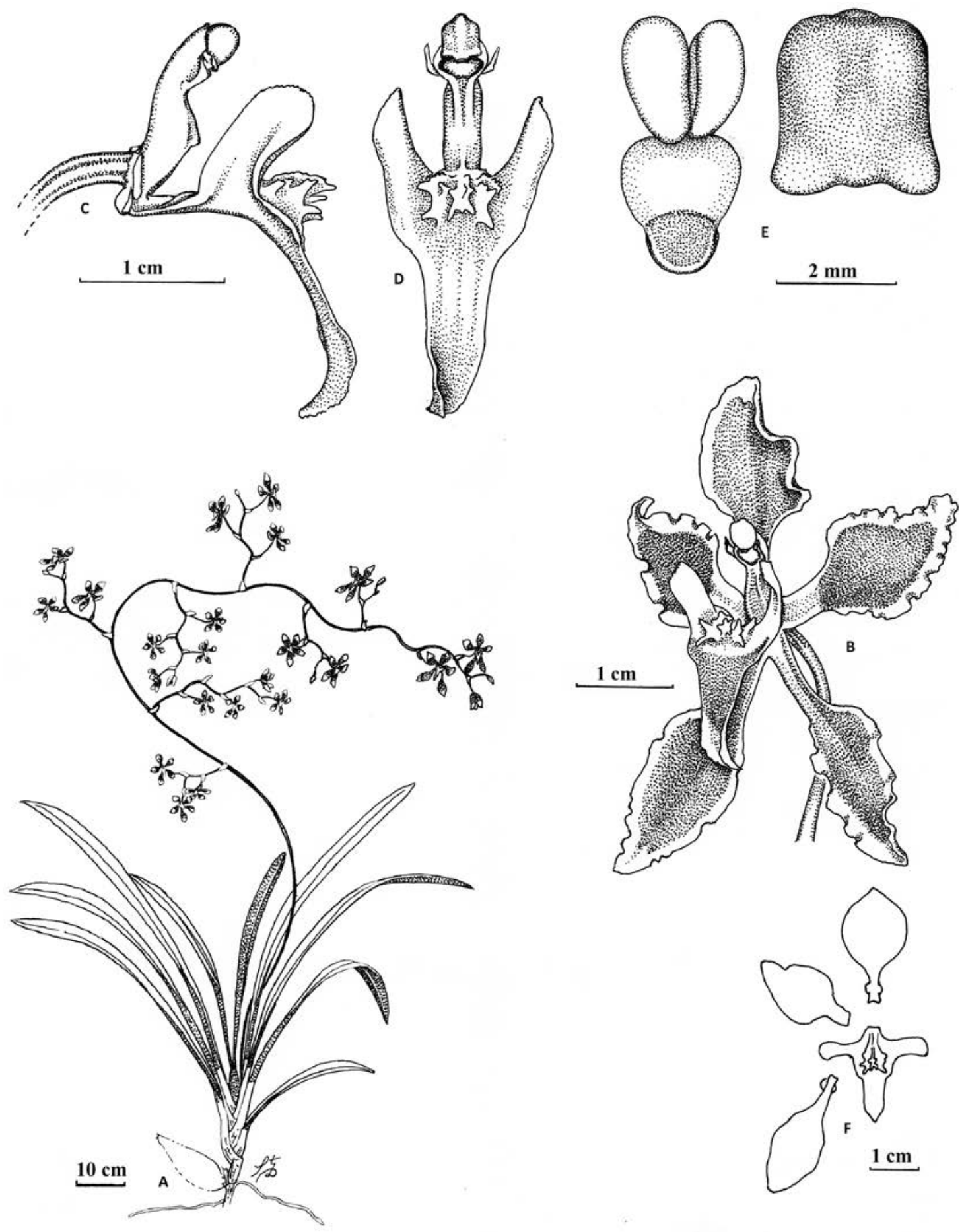

Figure. 1. Cyrtochilum deburghgraeveanum. A - Plant habit. B - Flower. C - Column-lip lateral view. D - Column-lip frontal view. E - Pollinarium and anthercap. F — Flower dissected. Drawn from the holotype by Stig Dalström. 
angular, laterally flattened, denticulate keels that are placed on each side of the rectangularly angulate central keel; column basally white with pale yellow on the ventral side, then brown, erect in a ca $90^{\circ}$ angle from the base of the lip, slender and clavate, slightly sigmoid, with a slight swelling near the middle on the ventral side, with two parallel longitudinal keels below the stigma, where a pair of lateral, erect and falcate, slightly unequally bilobed to digitate and pointed wings emerge, $c a .11 \mathrm{~mm}$ long; anther cap yellow to purplish brown, campanulate with a pale green dorsal lobule; pollinarium of two pyriform, folded pollinia on a broadly obovate, slightly concave, $c a$. $1 \mathrm{~mm}$ long stipe, on a pulvinate viscidium.

EponYmY: Named in honor of Guido Deburghgraeve of Liedekerke, Belgium, whose support and contributions to the knowledge of Oncidiinae orchids has been substantial for many years.

Cyrtochilum deburghraeveanum is similar to $C$. cordatum but differs in the rounded and white sidelobes of the lip versus pointed and brown to purple ones, bordered with white for $C$. cordatum. The callus of $C$. cordatum is also more elaborate with additional lateral teeth next to the main central structure.

Cyrtochilum deburghgraeveanum is only known from the heavily deforested montane area of northern Peru, where its existence is severely threatened by senseless destruction of the natural habitats and the depletion of the country's rich biodiversity.

\section{Cyrtochilum ruizii Dalström \& Deburghgraeve, $s p$.} nov.

TYPE: Peru, Cajamarca, Incahuási, alt. ca $2700 \mathrm{~m}, \mathrm{~S}$ $06^{\circ}$ 26,700'; W 079 01,177', collected by Saul Ruiz, May 23, 2011, S. Dalström 3495 (holotype, USM). FIG. 2.

Cyrtochilo cordato (Lind1.) Kraenzl. et Cyrtochilo deburghgraeveano Dalström \& S.Ruíz similis, sed colore petalibus, lobulis lateralibus et callo labelli differt.

Epiphytic or terrestrial herb. Pseudobulbs caespitose, ovoid, unifoliate or bifoliate, surrounded basally by distichous, foliaceous sheaths. Leaves subpetiolate, conduplicate, obovate, obtuse to acuminate (no vegetative parts were included in the type specimen, diagnosis based on observations only). Inflorescence axillary, from the base of the uppermost sheaths, erect, then wiry and flexuous, to more than 1 meter long panicle (tip broken off on type specimen, but much longer inflorescences have been observed), with widely spaced few-flowered side branches. Bracts appressed, involute, cucullate, $10-12 \mathrm{~mm}$ long. Pedicel with ovary 20-30 mm long. Flowers stellate to slightly campanulate, sometimes irregular but showy; dorsal sepal brown with whitish edges and apex, spathulate with basal auricles, then laminate, broadly ovate, obtuse, widely undulate, $22-28 \times c a .15 \mathrm{~mm}$; lateral sepals similar in color, spathulate with basal auricles, then laminate, broadly ovate, obtuse, widely undulate and slightly oblique, $27-28 \times c a .13 \mathrm{~mm}$; petals basally whitish to pale pink, then with brown irregular mottling and a white apical third, shortly and broadly spathulate, then laminate, broadly ovate, obtuse, widely undulate, 21-23 $\times c a .15 \mathrm{~mm}$; lip yellowish brown with yellow around the callus, rigidly attached to the base of the column, cuneate, then hastate to cordate, trilobate with erect, obovate, weakly serrate and oblique side-lobes, and a narrowly triangular, ligulate, apically slightly convolute and recurved, acute to slightly acuminate front-lobe, $c a$. $22 \times 22 \mathrm{~mm}$; callus yellow, of three low, longitudinal keels, emerging from the base and extending to near the frontlobe, spreading, the lateral pair ends in raised, blunt, angulate keels, while the central keel continues with two new emerging, lateral, spreading keels on each side of the angular, nose-like apex; column basally pale yellow then brownish with brown wings with yellow edge, erect in an almost $90^{\circ}$ angle from the basal part of the lip, slender and clavate, slightly sigmoid, with a slight swelling and two parallel short keels at the middle of the ventral side below the stigma, and with a pair of falcate, digitate wings on each side of the stigma, $c a .13$ $\mathrm{mm}$ long; anther cap reddish brown, campanulate, with a pale green dorsal lobule; pollinarium of two pyriform, folded pollinia on a broadly rotund and slightly concave, ca. $1.5 \mathrm{~mm}$ long stipe, on a ovate, pulvinate viscidium.

Additional SPECimens SEen: Ecuador, Loja, "Rio Zenen", color transparency by R. Thompson (Dalström photo archives).

Eponymy: Named in honor of Saul Ruíz Perez, a resident of Lima who collected the type plant and 

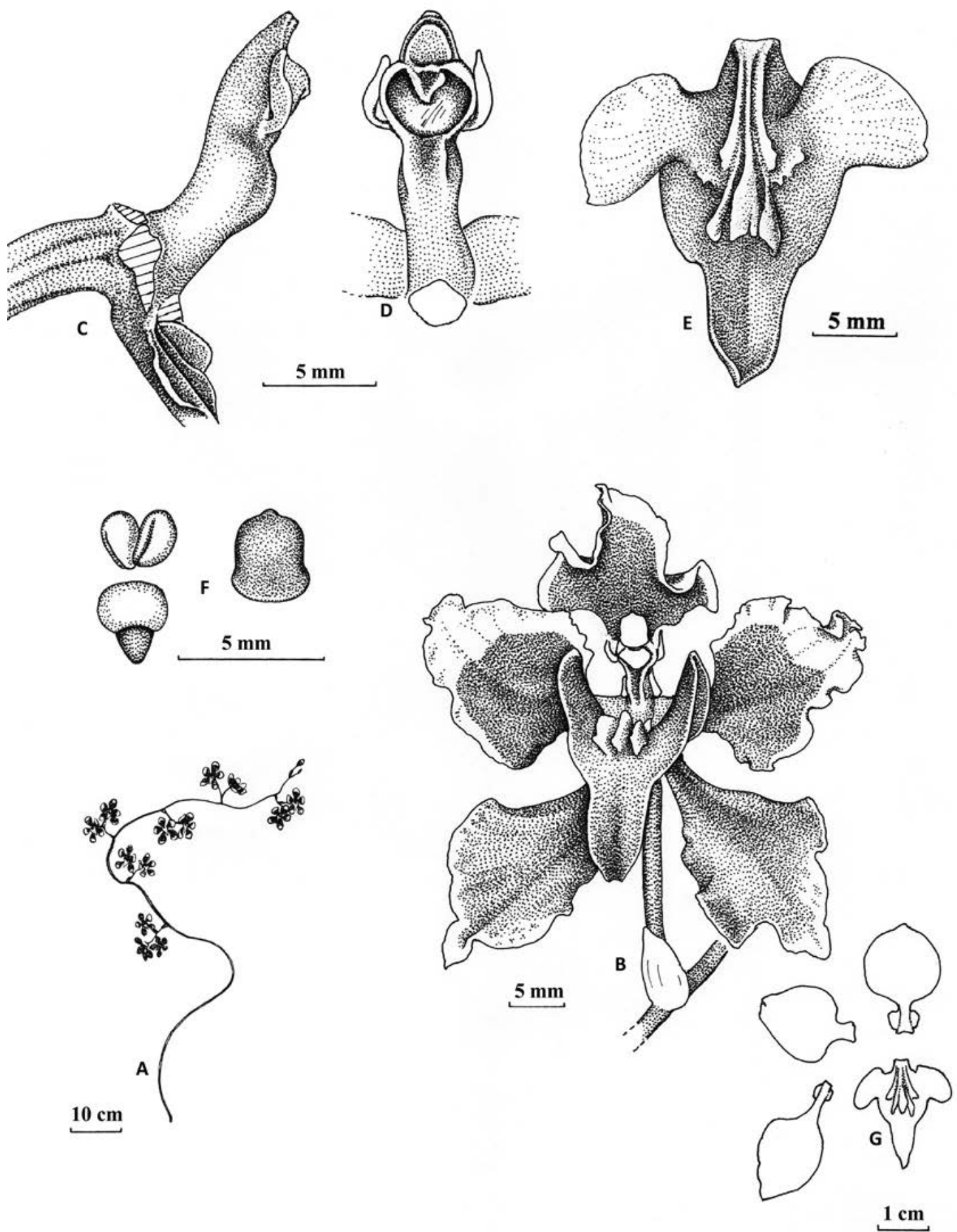

Figure 2. Cyrtochilum ruizii. A - Inflorescence. B. Flower. C - Column lateral view. D - Column frontal view. E - Lip flattened. F — Pollinarium and anther cap. G - Flower dissected. Drawn from holotype by Stig Dalström. 

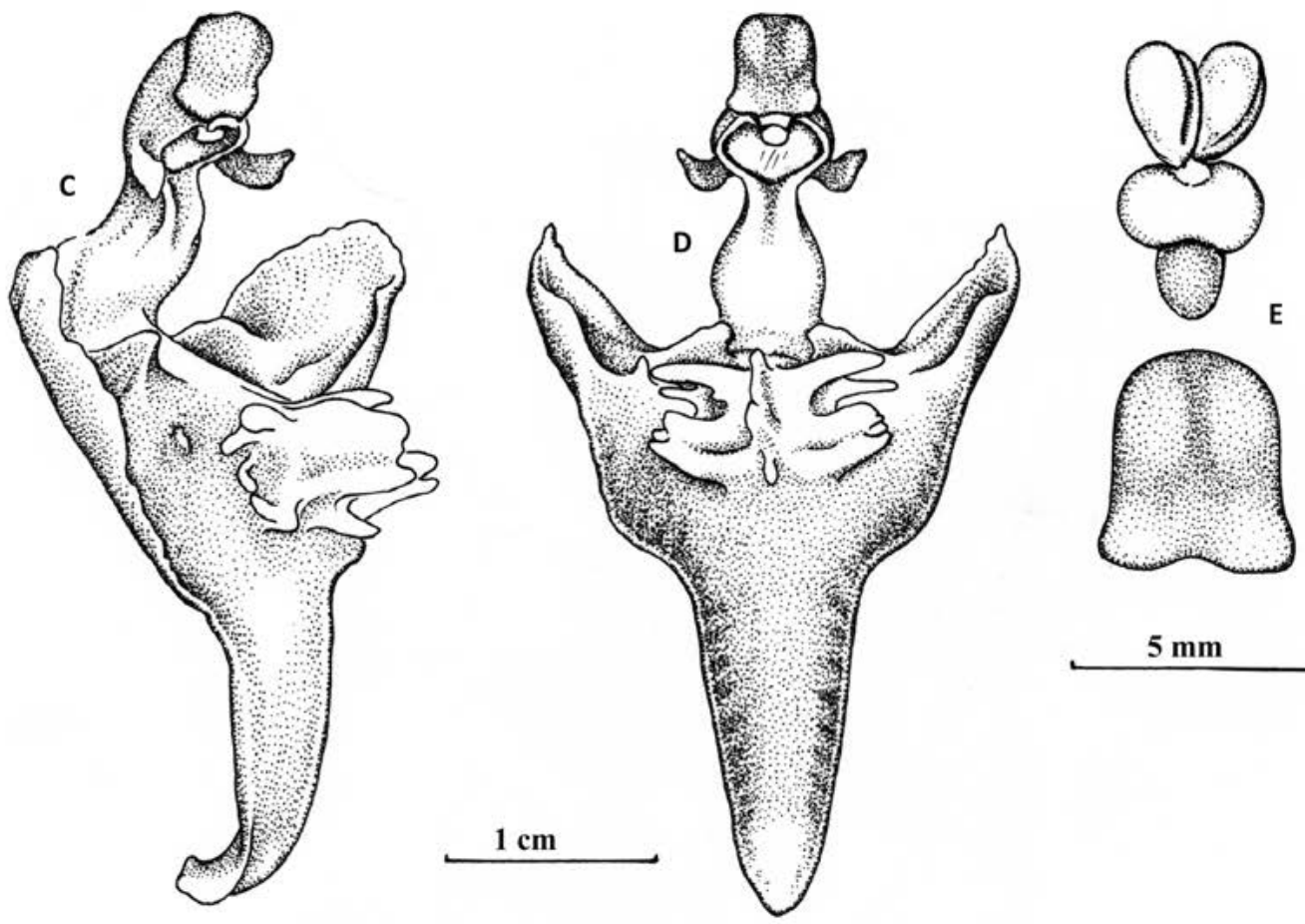

$5 \mathrm{~mm}$
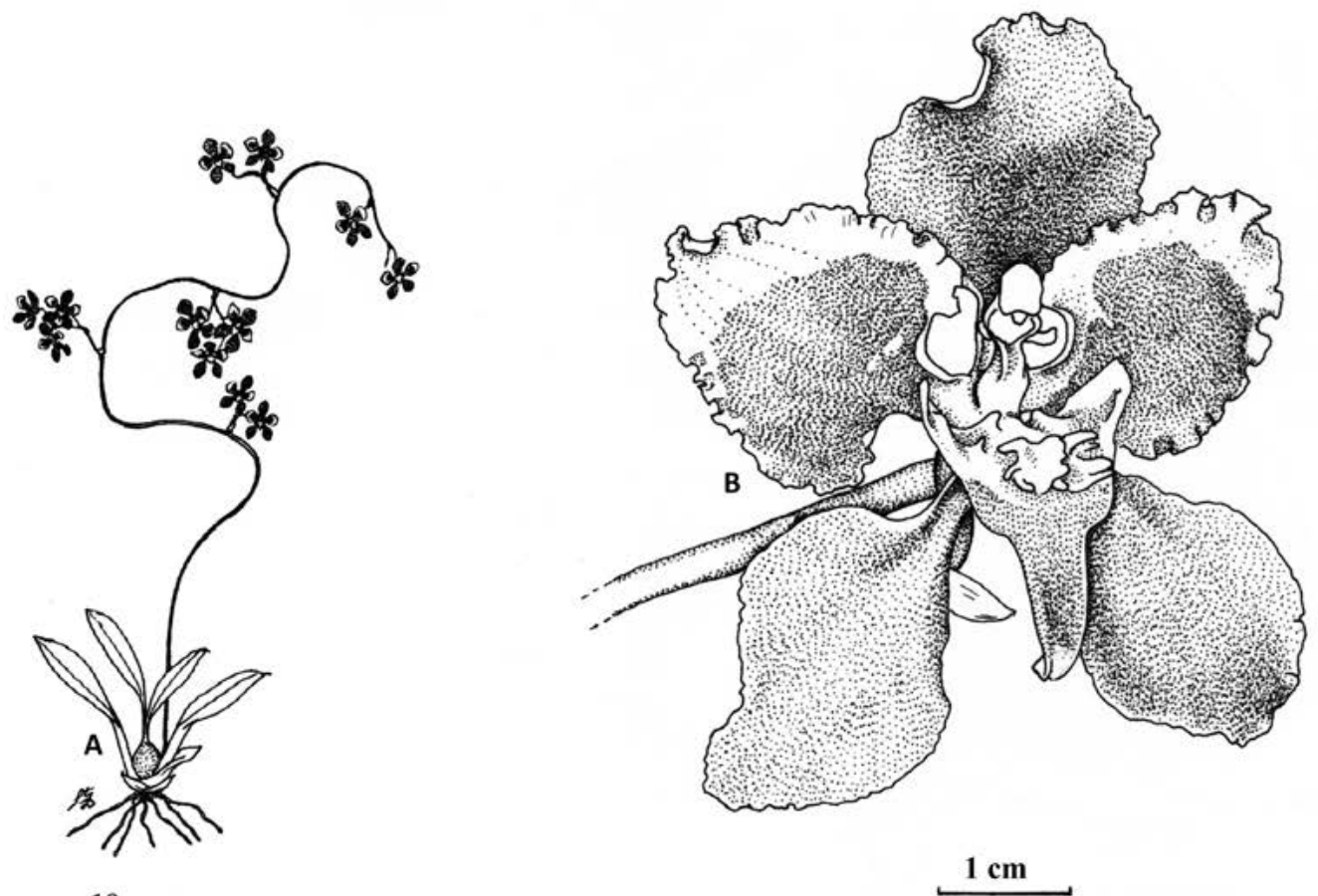

$10 \mathrm{~cm}$

Figure 3. Cyrtochilum xanthocinctum. A - Plant habit. B - Flower. C - Column-lip lateral view. D - Column-lip frontal view. E - Pollinarium and anther cap. Drawn from holotype by Stig Dalström. 
who tirelessly continues to contribute knowledge of Peruvian orchids.

Cyrtochilum ruizii differs from both $C$. deburghgraeveanum and C. cordatum by the large and widely rounded, slightly spreading, unicolored brown lateral lobes of the lip, and by the attractive white petals, covered basally by a large brown blotch.

This apparently very rare species was previously known only from a color transparency, photographed some twenty-five years ago in a rather heavily deforested area north of Loja, Ecuador. No plant material ever surfaced. The second observation, and first known collection, constitutes the type of this species, which was found in a similarly deforested montane area in northern Peru. Only fractions of the rich and lush cloud forest that once covered the Peruvian Andes remain today, particularly in the northern regions. These remnants will, no doubt, be altogether gone within a few years. Fortunately, a few individual plants have been secured and artificial propagation will soon ensure the survival of this highly endangered and attractive orchid.

Cyrtochilum ruizii is similar to Cyrtochilum cordatum (Lindl.) Kraenzl., and Cyrtochilum deburghgraeveanum but is most easily distinguished by the brightly patterned petals, and the solid brown lip with a yellow callus.

Cyrtochilum xanthocinctum Dalström \& S.Ruíz, sp. nov.

TYPE: Peru, Amazonas, Chachapoyas, Molinopampa, alt. ca $2400 \mathrm{~m}$, collected by S. Ruíz in March 2011, S. Dalström 3450 (holotype, USM). FIG. 3.

Cyrtochilo macrantho Lindl. similis, sed colore petalibus, lobulis lateralibus et callo labelli differt.

Epiphytic herb. Pseudobulbs caespitose, broadly ovoid, ca $7.5 \times 4.5 \mathrm{~cm}$, bifoliate, surrounded basally by 4 to 6 distichous, sheaths, the uppermost foliaceous. Leaves subpetiolate, conduplicate, obovate, acute, $13-17 \times c a .3 .5 \mathrm{~cm}$. Inflorescence axillary, from the uppermost sheaths, erect then wiry, to ca $150 \mathrm{~cm}$ long. Bracts large and conspicous, involute cucullate, $c a$. 10$15 \mathrm{~mm}$ long. Pedicel with ovary ca. $5 \mathrm{~cm}$ long. Flower stellate and showy; dorsal sepal brown, spathulate with basal auricles, then cordate laminate, broadly ovate, obtuse and apiculate, widely undulate, $c a .28 \times$ $23 \mathrm{~mm}$; lateral sepals similar in color, spathulate with basal auricles, then cordate laminate, ovate, rounded obtuse, widely undulate, $35 \times 20 \mathrm{~mm}$; petals basally white, then with a large brown blotch, bordered with yellow, broadly and shortly spathulate, then cordate laminate, ovate, rounded obtuse, densely undulate, $27 \times 22 \mathrm{~mm}$; lip basally pale lilac, then white, and then brown with a lighter apex, rigidly attached to the base of the column, cordate, trilobate with a pair of basal, erect and slightly incurved denticles, and widely spreading semi-erect and slightly convcave, angular side-lobes, with or without additional erect minor denticles, and a narrowly triangulate, ligulate, slightly recurved, acute frontlobe, $23 \times 20 \mathrm{~mm}$; callus whitish, of a fleshy central, longitudinal, low keel turning into an erect structure near the base of the front-lobe, similar to some strange aircraft with spreading double pairs of wings; column basally yellow then brown, stout, erect in a ca $90^{\circ}$ angle from the base of the lip, slightly sigmoid, with a pair of parallel longitudinal ventral keels below the stigma, and with lateral, oblique obdeltoid, wine-red spreading wings, $c a$. $12 \mathrm{~mm}$ long; anther cap brown, campanulate, with a slight, purple dorsal lobule; pollinarium of two pyriform/globose cleft (or folded) pollinia on a broadly rotund, slightly concave $c a$. $1.5 \mathrm{~mm}$ long stipe on an oval, pulvinate viscidium.

AdDitional SPECIMENS SEen: Only a color transparency of a cultivated plant has been seen of this elusive and attractive species. The plant apparently died shortly after the photo was taken.

Eтymology: In reference to the attractive yellow borders of the petals.

Cyrtochilum xanthocinctum is only known from the heavily deforested area near the town of Molinopampa in northern Peru. Only small patches remain of the forest and the fate of this beautiful orchid is gloomy to say the least. Two plants were rescued from a scrubby patch of previously burnt vegetation and hopefully artificial propagation will ensure this spectacular species survival.

Although morphologically similar to the sympatric Cyrtochilum macranthum (Lindl.) Kraenzl., Cyrtochilum xanthoxinctum is easily recognized by 
the brown petals with strikingly contrasting yellow borders. Also the lateral callus keels on the lip are more laterally spreading in our new species.

ACKNOWLEDGMENTS. The authors thank the staff at the Instituto Recursos Naturales (INRENA), and Betty Millán at the Universidad de San Marcos, Museo de Historia Natural, Lima, for aiding in providing the necessary permits. We thank Wesley Higgins and Franco Pupulin for assistance with the manuscript, Ricardo Fernández for assistance at the USM herbarium, and a gracious thank you to Manolo Arias, his family and staff for generous logistic support. All plant material involved in this article was acquired in accordance with collecting permit 0283-2010-AG-DGFFS-DGEFFS.

\section{LiterATURE CITED}

Williams, N.H., M.W. Chase, T. Fulcher and W.M. Whitten. 2001a. Molecular systematics of the Oncidiinae based on evidence from four DNA sequence regions: expanded circumscriptions of Cyrtochilum, Erycina, Otoglossum, and Trichocentrum and a new genus (Orchidaceae) Lindleyana 16(2): 113-139.

Williams, N.H., M.W. Chase and W.M. Whitten. 2001b. Phylogenetic positions of Miltoniopsis, Caucaea, a new genus, Cyrtochiloides, and Oncidium phymatochilum (Orchidaceae: Oncidiinae) based on nuclear and plastid DNA data. Lindleyana 16(2):272-285. 